\title{
Recovery of ammonia from anaerobically digested manure using gas-permeable
}

\section{membranes}

\author{
Maria Cruz García-González ${ }^{*}$, Matias B. Vanotti², Ariel A. Szogi²
}

${ }^{1}$ Agricultural Technological Institute of Castilla and León Ctra. Burgos, km.119 - 47071 - Valladolid - Spain. 2United States Department of Agriculture - Agricultural Research Service - Coastal Plains Soil, Water and Plant Research Center - 2611 W. Lucas St. - Florence - SC USA.

*Corresponding author <gargonmi@itacyl.es>

Edited by: Airton Kunz

Received April 10, 2015

Accepted September 30, 2015

\begin{abstract}
Nitrogen (N) can be recovered from different types of wastewaters. Among these wastewaters, anaerobically digested swine manure (digestate) has the highest $\mathrm{N}$ content in ammonia form $\left(\mathrm{NH}_{3}\right)$. It is desirable to reduce $\mathrm{N}$ in digestate effluents to safely incorporate them in arable soil in $\mathrm{N}$ vulnerable zones (NVZ) and to mitigate $\mathrm{NH}_{3}$ emissions during $\mathrm{N}$ land application. Additional benefit is to minimize inhibition of the anaerobic process by removing $\mathrm{NH}_{3}$ during the anaerobic digestion process. This work aimed to apply the gas-permeable membrane technology to evaluate ammonia $\left(\mathrm{NH}_{3}\right)$ recovery from high-ammonia digested swine manure. Anaerobically digested swine manure with $\mathrm{NH}_{4}{ }^{+}$content of $4,293 \mathrm{mg} \mathrm{N} \mathrm{L}^{-1}$ was reduced by $91 \%$ (to $381 \mathrm{mg} \mathrm{N} \mathrm{L}^{-1}$ ) during the 32-day experiment. Although the results showed a total $\mathrm{N}$ recovery efficiency of $71 \%$, it is possible to increase this recovery efficiency to $>90 \%$ by adjusting the area of the membrane system to match the high free ammonia concentration (FA) in digested swine manure. Moreover, final digestate $\mathrm{pH}$ and alkalinity were kept around 8.1 and $8,923 \mathrm{mg}$ $\mathrm{CaCO}_{3} \mathrm{~L}^{-1}$, which are convenient for the anaerobic process or incorporation in arable soil when the process is finished.
\end{abstract}

Keywords: $\mathrm{N}$ removal, digestate, manure management, membrane technology

\section{Introduction}

Anaerobic digestion (AD) is a widely used technique with an increasing number of full biogas-plants under operation for organic solid waste treatment and energy recovery (Carrosio, 2014). The rise in environmental concerns associated with energy production and $\mathrm{CO}_{2}$ mitigation policies has renewed interest in digestion technologies.

Ammonia inhibition in $\mathrm{AD}$ has been reported with a wide range of inhibiting $\mathrm{NH}_{3}$, because of differences in the nature of substrates, inocula, environmental conditions and acclimation periods (Chen et al., 2008). Sung and Liu (2003) and Procházka et al. (2012) showed that $\mathrm{NH}_{3}$ concentrations higher than $3,000 \mathrm{mg} \mathrm{L}^{-1}$ could cause obvious inhibition of methanogenesis. In another study, Hejnfelt and Angelidaki (2009) concluded that $\mathrm{NH}_{3}$ levels of $1,500-7,000 \mathrm{mg} \mathrm{L}^{-1}$ caused a decrease in methane production.

The gas-permeable membrane technology (GPMT) has been successfully used to recover $\mathrm{NH}_{3}$ from swine manure (García-Gonzalez and Vanotti, 2015; García-Gonzalez et al., 2015). This technology can be combined with other treatment technologies such as $\mathrm{AD}$ and phosphorus recovery to improve their performance (Vanotti and Szogi, 2015). In the case of anaerobic digestion, the process can be applied inside a digester to remove ammonia without damaging the carbonaceous material and therefore improving the anaerobic process, as reported by Garcia-Gonzalez and Vanotti (2015). Other studies reported AD performance improvement in semi-batch experiments using GPMT to treat slaughterhouse waste (Lauterbock et al., 2014). Hence, if a large quantity of $\mathrm{NH}_{3}$ is removed from digestate, the typical inhibition caused by this compound will be minimized, improving both $\mathrm{AD}$ and methane production.
Nowadays, AD is an important technology and strategy to manage manure worldwide and in many countries, with high number of NVZ (Nitrate Vulnerable Zones), thus, land application of the digestate is an important strategy to recycle nutrients and organic matter. However, the application is limited by the $\mathrm{N}$ content of digestate (European Council, 1991). Reducing ammonia from digestate using GPMT could help reduce environmental pressure in these intensive livestock production areas. This study aimed to apply GPMT to evaluate $\mathrm{NH}_{3}$ recovery from digested swine manure at lab scale. The $\mathrm{pH}$ of the digested manure was kept above 7.7 by adding sodium hydroxide when necessary to enhance ammonia capture by the membrane.

\section{Materials and Methods}

\section{Experimental procedure}

A batch experiment was conducted in $2 \mathrm{~L}$ wastewater vessels consisting of polyethylene terephthalate (PET) plastic jars for an effective digestate volume of $1.3 \mathrm{~L}$ using the experimental device and diagram described in Garcia-Gonzalez and Vanotti (2015). The acid tank consisted of $500 \mathrm{~mL}$ Erlenmeyer flasks containing $280 \mathrm{~mL} 1 \mathrm{~N} \mathrm{H}_{2} \mathrm{SO}_{4}$. A diaphragm pump (Alldos, TrueDos model, Denmark) was used to continuously circulate the acid through tubular membranes inside the digestate vessels and back into the acid tank using a constant flow rate of $5.8 \mathrm{~L} \mathrm{~d}^{-1}$. The $\mathrm{pH}$ in the acidic tank increased, as ammonia was captured by the membrane, therefore, the acid $\mathrm{pH}$ was adjusted to keep it below 1.5. Gas-permeable tubing $(60 \mathrm{~cm}$ long, $10.25 \mathrm{~mm}$ outer diameter and $0.75 \mathrm{~mm}$ wall thickness) made of expanded polyetrafluoroethylene (ePTFE) (Phillips Scientific Inc., Rock 
Hill, SC) was used for $\mathrm{NH}_{3}$ capture. The membrane manifolds were submerged in digestate contained in PET jars, which were kept closed but not airtight. Ports were installed on top of the reactor vessels to obtain samples and monitor $\mathrm{pH}$. The digestate was continuously agitated using magnetic stirrers.

The experiment was carried out to evaluate $\mathrm{N}$ recovery from anaerobically digested swine manure. Chemical characteristics are shown in Table 1 . The biogas plant was located in Salamanca (Spain). The plant was a co-digestion plant treating the manure of a farm with 6,000 fattening pigs as well as agro-food wastes. Digestate was collected directly from the mesophilic digester in plastic containers, transported in coolers to the laboratory and subsequently stored at $4{ }^{\circ} \mathrm{C}$ for further use.

The $\mathrm{pH}$ of the digestate was adjusted whenever it decreased below 7.7, according to (Garcia-Gonzalez and Vanotti, 2015). This adjustment consisted in increasing the digestate $\mathrm{pH}$ using sodium hydroxide $(5 \mathrm{~N})$, which was added when necessary to endpoint $\mathrm{pH}$ 8.5-9.0. Digestate samples from the vessels and acidic solution samples from the concentrator tank were collected daily to monitor $\mathrm{pH}$, alkalinity and $\mathrm{NH}_{4}^{+}$. All experiments were carried out in duplicate and results were expressed as means. The test was run at room temperature to simulate ammonia recovery from the digested manure in a system external to the anaerobic digestion.

\section{Analytical methods}

Analyses of total solids (TS), volatile solids (VS), total chemical oxygen demand (CODt), total Kjeldahl nitrogen (TKN) and total phosphorus (TP) were performed in duplicate in accordance with APHA Standard Methods (1989). The $\mathrm{pH}$ and total alkalinity were monitored using a pH meter Crison Basic 20 (Crison Instruments S.A., Barcelona, Spain). Total alkalinity was obtained by measuring the amount of standardized sulphuric acid needed to bring the sample to a $\mathrm{pH}$ endpoint of 4.5 and expressed as $\mathrm{mg} \mathrm{CaCO} \mathrm{L}^{-1} . \mathrm{NO}_{3}{ }^{-}$and $\mathrm{NO}_{2}{ }^{-}$were monitored using colorimetric strips (MQuant ${ }^{\mathrm{TM}}$, Merck). $\mathrm{NH}_{4}{ }^{+}$concentrations were determined using a $\mathrm{NH}_{3}$ gassensing electrode Orion 900/200 (Thermo Electron Cor-

Table 1 - Chemical characteristics of the digestate at the beginning and at the end of each batch experiment. The standard deviation of duplicate experiments are shown in parenthesis.

\begin{tabular}{lrr}
\hline & \multicolumn{1}{c}{ Initial } & \multicolumn{1}{c}{ Final } \\
\hline pH & $8.01(0)$ & $8.11(0.01)$ \\
CODt $\left(\mathrm{g} \mathrm{L}^{-1}\right)$ & $27(1)$ & $22(0.23)$ \\
$\mathrm{TS}\left(\mathrm{g} \mathrm{L}^{-1}\right)$ & $35(0.32)$ & $36(0.54)$ \\
$\mathrm{VS}\left(\mathrm{g} \mathrm{L}^{-1}\right)$ & $25(0.33)$ & $22(0.20)$ \\
$\mathrm{Pt}\left(\mathrm{mg} \mathrm{L}^{-1}\right)$ & $771(3.54)$ & $645(1.06)$ \\
$\mathrm{TKN}\left(\mathrm{mgN} \mathrm{L}^{-1}\right)$ & $4,690(44)$ & $1,244(89)$ \\
$\mathrm{NH}_{4}^{+}\left(\mathrm{mgN} \mathrm{L}^{-1}\right)$ & $4,293(0)$ & $381(55)$ \\
$\mathrm{NO}_{3}^{-}+\mathrm{NO}_{2}^{-}\left(\mathrm{mg} \mathrm{L}^{-1}\right)$ & 0 & 0 \\
Alkalinity $\left(\mathrm{mgCaCO}_{3} \mathrm{~L}^{-1}\right)$ & $19,038(0)$ & $8,923(947)$ \\
\hline
\end{tabular}

poration, Beverly, USA) after adjusting sample to $\mathrm{pH}$ $>11$. Free $\mathrm{NH}_{3}(\mathrm{FA})$ was quantified theoretically according to Eq. (1), where $\mathrm{NH}_{3}$ was the FA content and $\mathrm{TNH}_{3}$ was the total $\mathrm{NH}_{4}{ }^{+}$(measured in the $\mathrm{NH}_{4}{ }^{+}$determination described above) (Hansen et al., 1998):

$$
\left[\mathrm{NH}_{3}\right] /\left[\mathrm{TNH}_{3}\right]=1+\left(\frac{10^{-p H}}{10^{-(009018+272992 / T}}\right)^{-1}
$$

\section{Results and Discussion}

$\mathrm{NH}_{4}{ }^{+}$concentration in digestate decreased from $4,293 \pm 0 \mathrm{mg} \mathrm{N} \mathrm{L}^{-1}$ to $381 \pm 55 \mathrm{mg} \mathrm{N} \mathrm{L}^{-1}$ in the 32 days of experiment (Figure 1). Ammonia capture by the membrane continuously increased until day 25, after which, little or no more $\mathrm{NH}_{3}$ was recovered in the acidic solution. Similarly, $\mathrm{NH}_{4}^{+}$in digestate decreased little at the end of the experiment, from 433 (day 27) to 381 (day 32) $\mathrm{mg} \mathrm{N} \mathrm{L}^{-1}$ at the end of the experiment (Figure 1). The acidic solution was the same during the entire experiment, thus, the recirculation of this liquid occurs in a closed loop between the treatment vessel and the acid tank, which achieved an $\mathrm{NH}_{4}{ }^{+}$concentration in the recovery solution $\left(11,200 \pm 1,100 \mathrm{mg} \mathrm{N} \mathrm{L}^{-1}\right)$ of almost three-fold higher than in digestate $14,293 \mathrm{mg} \mathrm{N} \mathrm{L}^{-1}$; Figure 1). Sixty-two percent of $\mathrm{NH}_{4}^{+}$removed from digestate during the experimental period was recovered in the acidic solution. These findings are in agreement with those reported by García-Gonzalez and Vanotti (2015) who observed a high $\mathrm{N}$ recovery from manure with different $\mathrm{NH}_{4}{ }^{+}$strengths using GPMT.

The rate of $\mathrm{NH}_{4}{ }^{+}$recovery was not linear and followed a 2nd-order curve (Figure 2), meaning that the $\mathrm{NH}_{3}$ capture rate was higher during the first days, and decreased as it was being depleted from the manure.

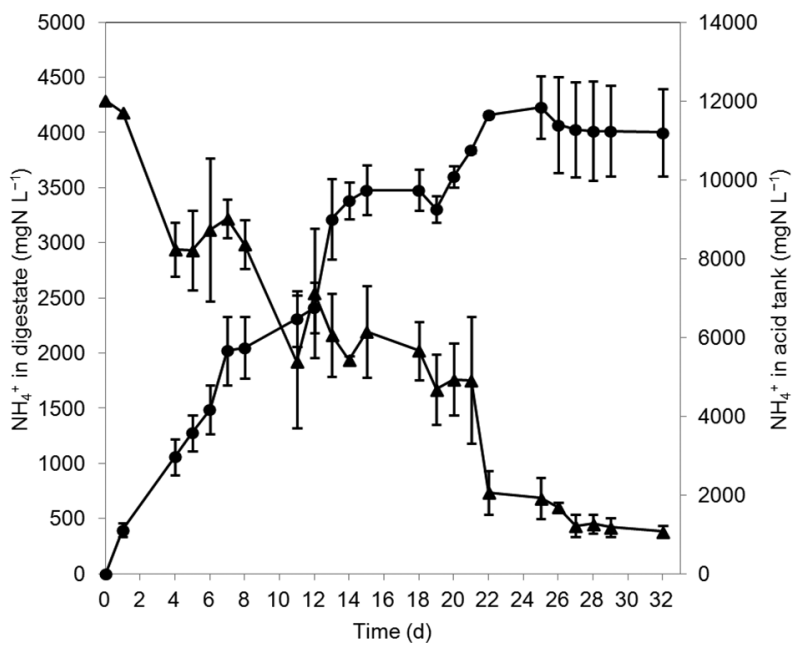

Figure 1 - Removal of ammonia in digestate $(\boldsymbol{\Delta})$ by the gas membrane system and recovery and concentration in the acid tank (@). The error bars are the standard deviation of duplicate experiments. 


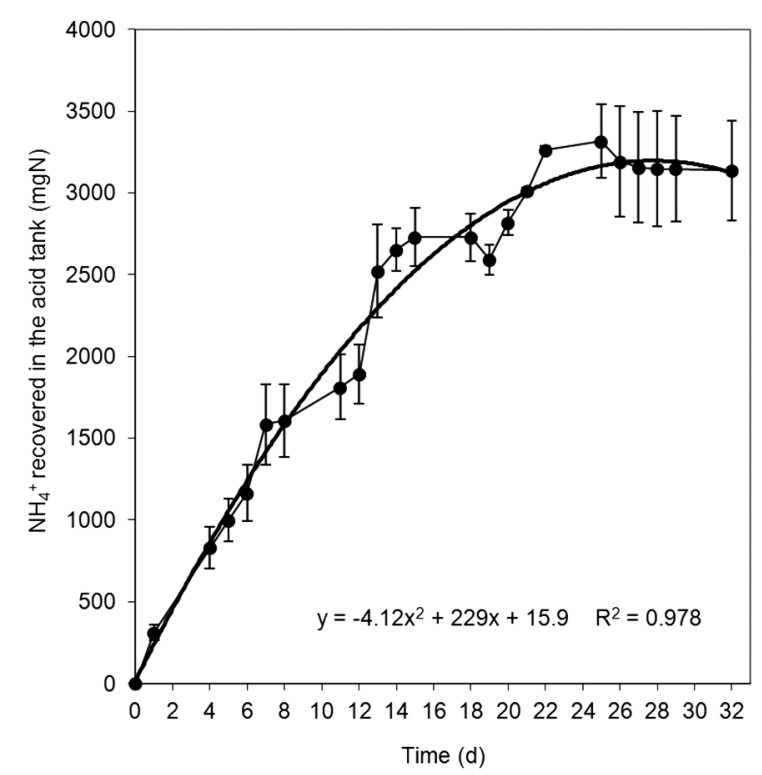

Figure 2 - Mass of ammonia recovered in the acid tank. A secondorder equation and $\mathrm{R}^{2}$ are represented. The error bars are the standard deviation of duplicate experiments.

Similar to what was observed in raw swine manure, when FA content in the manure was low, the rate of $\mathrm{NH}_{3}$ captured by the membrane decreased (García-Gonzalez and Vanotti, 2015).

Most of the $\mathrm{NH}_{3}$ recovery occurred during the first 25 days of the experimental period, with an average recovery rate of $405 \mathrm{mg} \mathrm{N} \mathrm{L}^{-1} \mathrm{~d}^{-1}$ and a high $\mathrm{NH}_{4}^{+}$recovery efficiency of $71 \%$ (Table 2 ). The average recovery rate during the second part of the batch (25-32 days) was $81 \mathrm{mg} \mathrm{N} \mathrm{L}{ }^{-1} \mathrm{~d}^{-1}$ and the corresponding $\mathrm{NH}_{4}{ }^{+}$recovery efficiency was $45 \%$ of the remaining $\mathrm{NH}_{4}{ }^{+}$. The inability of the membrane to recover additional $\mathrm{N}$ from day 25 to the end of the experiment can be explained by the $\mathrm{NH}_{3}$ content in digestate. The average free $\mathrm{NH}_{3}$ in digestate until day 25 of the experiment was $178 \mathrm{mg} \mathrm{N}$ $\mathrm{L}^{-1}$, however, from that day until the end of the experiment, average free $\mathrm{NH}_{3}$ in digestate decreased to $69 \mathrm{mg}$ $\mathrm{N} \mathrm{L}^{-1}$. This means that $\mathrm{NH}_{3}$ concentration in digestate was low and permeated slowly through the membrane. Therefore, it was necessary to keep a high level of free $\mathrm{NH}_{3}$ to continuously recover $\mathrm{N}$, which was achieved by keeping the $\mathrm{pH}$ of digestate above 8.5 (García-Gonzalez and Vanotti, 2015). As $\mathrm{NH}_{3}$ was removed, the $\mathrm{pH}$ of the digestate was keep around 8.0 for the first 19 days of the experiment by adjusting it with alkali on days 21 and 27 (Figure 3). This indicates that, although alkalinity was consumed to neutralize digestate acidification due to $\mathrm{NH}_{3}$ removal, the buffer capacity of digestate was very high. Therefore, a $53 \%$ decrease in the digestate alkalinity was observed with a consumption of 10,115 \pm 947 mg $\mathrm{CaCO}_{3} \mathrm{~L}^{-1}$ (Figure 3).

In contrast with previous studies carried out with raw manure, both the maximum $\mathrm{NH}_{4}{ }^{+}$recovery rate and

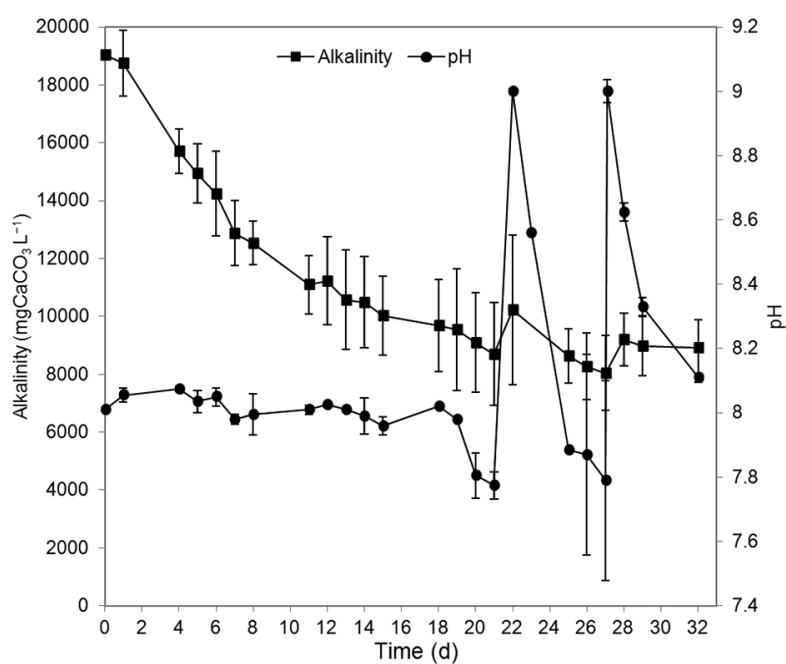

Figure 3 - Changes in $\mathrm{pH}$ and alkalinity of digestate along the experimental period. The $\mathrm{pH}$ was corrected on days 21 and 27. The error bars are the standard deviation of duplicate experiments.

the average $\mathrm{NH}_{4}^{+}$recovery rate obtained in this study were very high as well as the FA content in the digestate (Table 3). According to previous studies, mass recovery of $\mathrm{NH}_{4}{ }^{+}$through the membrane increased as FA content increased in manure because of $\mathrm{pH}$ adjustment (with aeration treatment or alkali addition). However, in the present study, FA content remained high during the first 25 days of experimentation (178 $\mathrm{mg} \mathrm{N} \mathrm{L}^{-1}$ ). This high FA content allowed active permeation of $\mathrm{NH}_{3}$ through the membrane. Yet, the absorption capacity of the membrane was not enough to recover all FA in digestate and a fraction of $\mathrm{NH}_{4}{ }^{+}$was volatilized, as the reaction vessels were not airtight. This volatilization loss was significant in the mass balance, representing $1,370 \mathrm{mg} \mathrm{N}$ or $25 \%$ of initial $\mathrm{NH}_{4}{ }^{+}$. These volatilization losses were high compared with results from García-Gonzalez and Vanotti (2015), who treated raw manure and obtained volatilization losses of $187 \mathrm{mg} \mathrm{N}$ (8\% of initial $\mathrm{NH}_{4}{ }^{+}$), also compared with results from García-Gonzalez et al. (2015) who obtained volatilization losses also in raw manure of 50 and $220 \mathrm{mg} \mathrm{N}$ (2 to $6 \%$ of initial $\mathrm{NH}_{4}^{+}$) using similar reactor vessels and tubular membrane length (Table 3). Thus, to recover all $\mathrm{N}$ and to avoid significant volatilization from digestate, the reaction device should be totally hermetic for the membrane manifold work at its maximum absorption capacity.

As previously mentioned, digestate from on-farm biogas plants is commonly used as fertilizer in countries with high intensive livestock pressure. Digested slurries have been found to be significant sources of ammonia $\left(\mathrm{NH}_{3}\right)$, methane $\left(\mathrm{CH}_{4}\right)$ and nitrous oxide $\left(\mathrm{N}_{2} \mathrm{O}\right)$ emissions (Amon et al., 2006; Bacenetti et al., 2013; Nkoa, 2014), with potential implications for local-to-regional climate (NRC, 2002; Ravishankara et al., 2009). Thus, an important challenge is to develop strategies that help to control the impact of agriculture on the environment, such 
Table 2 - Mass balances of the recovery of nitrogen in digestate using gas-permeable membranesa.

\begin{tabular}{|c|c|c|c|c|c|c|c|c|}
\hline Days in the batch ${ }^{b}$ & $\begin{array}{l}\text { Initial } \mathrm{NH}_{4}^{+}-\mathrm{N} \\
\text { in digestate }\end{array}$ & $\begin{array}{l}\text { Remained } \\
\mathrm{NH}_{4}{ }^{+}-\mathrm{N} \text { in } \\
\text { digestate }\end{array}$ & $\begin{array}{l}\mathrm{NH}_{4}^{+}-\mathrm{N} \\
\text { removed } \\
\text { from } \\
\text { digestate }^{\mathrm{c}}\end{array}$ & $\begin{array}{l}\mathrm{NH}_{4}{ }^{+}-\mathrm{N} \\
\text { recovered } \\
\text { in the acid } \\
\text { solution }\end{array}$ & $\begin{array}{l}\mathrm{NH}_{4}{ }^{+}-\mathrm{N} \\
\text { removal } \\
\text { efficiency }\end{array}$ & $\begin{array}{l}\mathrm{NH}_{4}{ }^{+}-\mathrm{N} \\
\text { recovery } \\
\text { efficiency }\end{array}$ & $\begin{array}{l}\text { Maximum } \\
\mathrm{NH}_{4}^{+}-\mathrm{N} \\
\text { recovery }^{\dagger} \\
\text { rate }^{f}\end{array}$ & $\begin{array}{c}\text { Average } \\
\mathrm{NH}_{4}^{+-} \mathrm{N} \\
\text { recovery } \\
\text { rate }\end{array}$ \\
\hline & & & $y$ & & - & & \multicolumn{2}{|c|}{$\mathrm{mg} \mathrm{NH}_{4}^{+-} \mathrm{N} \mathrm{L}^{-1} \mathrm{~d}^{-1}$} \\
\hline First part (0-25 days) & $5581(0)$ & $892(240)$ & $4689(240)$ & $3316(308)$ & 84 & 71 & 1244 & 405 \\
\hline Second part (25-32 days) & $892(240)$ & $495(71)$ & 396 (169) & $180(85)$ & 44 & 45 & 168 & 81 \\
\hline All (0-32 days) & $5581(0)$ & $495(71)$ & $5086(71)$ & 3136 (308) & 91 & 62 & 1244 & 324 \\
\hline
\end{tabular}

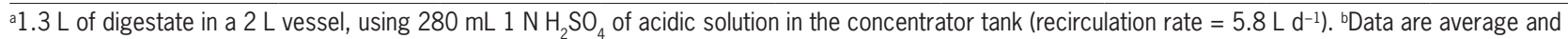
standard deviation of duplicate reactors during 32-day experiment. First row of data shows mass balances for the first 25 days of the batch when recovery was active. Second row shows mass balances for the following period (25-32 days). ${ }^{\mathrm{N}} \mathrm{NH}_{4}{ }^{+}$removed from digestate $=$initial $\mathrm{NH}_{4}{ }^{+}$in digestate - remained $\mathrm{NH}_{4}{ }^{+}$in digestate. ${ }^{\mathrm{d}} \mathrm{NH}_{4}{ }^{+}$removal efficiency $=\left(\mathrm{NH}_{4}{ }^{+}\right.$lost from digestate/initial $\mathrm{NH}_{4}{ }^{+}$in digestate $) \times 100 . \mathrm{eNH}_{4}{ }^{+}$recovery efficiency $=\left(\mathrm{NH}_{4}{ }^{+}\right.$recovered in the acidic solution/ $\mathrm{NH}_{4}{ }^{+}$lost from digestate) $\times 100$. ${ }^{4}$ Highest $\mathrm{NH}_{4}{ }^{+}$mass recovered in 1 day; $0.0323 \mathrm{~m}^{2}$ of membrane surface area.

Table 3 - Comparison of free ammonia (FA) and average $\mathrm{NH}_{4}{ }^{+}$recovery rate by the gas-permeable membrane reactor in digestate and manure from previous studies ${ }^{\text {. }}$.

\begin{tabular}{|c|c|c|c|c|c|c|c|}
\hline $\begin{array}{l}\text { Type of } \\
\text { wastewater }\end{array}$ & $\begin{array}{c}\text { Initial } \mathrm{NH}_{4}{ }^{+}-\mathrm{N} \\
\text { in manure } \\
\text { reactor }\end{array}$ & $\begin{array}{c}\mathrm{NH}_{4}{ }^{+}-\mathrm{N} \\
\text { volatilized } \\
\text { in the airb }\end{array}$ & $F A^{c}$ & $\begin{array}{l}\mathrm{NH}_{4}{ }^{+} \mathrm{N} \\
\text { recovery } \\
\text { efficiency }\end{array}$ & $\begin{array}{l}\text { Maximum } \\
\mathrm{NH}_{4}{ }^{+}-\mathrm{N} \\
\text { recovery rate }\end{array}$ & $\begin{array}{l}\text { Average } \\
\mathrm{NH}_{4}{ }^{+} \mathrm{N} \\
\text { recovery rate }\end{array}$ & Reference \\
\hline & \multicolumn{2}{|c|}{$\mathrm{mgN}$} & $\mathrm{mgN} \mathrm{L}^{-1}$ & $\%$ & \multicolumn{2}{|c|}{$\longrightarrow \mathrm{mgNH}_{4}{ }^{+}-\mathrm{N} \mathrm{L}^{-1} \mathrm{~d}^{-1} \longrightarrow$} & \\
\hline Manure $^{d}$ & 2310 & 187 & 45 & 91 & 412 & 148 & García-Gonzalez and Vanotti, 2015 \\
\hline Manure ${ }^{e}$ & 3410 & 50 & 80 & 99 & 780 & 184 & García-Gonzalez et al., 2015 \\
\hline Manure $^{f}$ & 3930 & 220 & 40 & 93 & 810 & 172 & García-Gonzalez et al., 2015 \\
\hline Digestateg & 5581 & 1373 & 178 & 71 & 1244 & 405 & This study \\
\hline
\end{tabular}

aThe reactors in all referenced studies contained a $60 \mathrm{~cm}$ length polyetrafluoroethylene (ePTFE) membrane tubing with a $0.0323 \mathrm{~m}^{2}$ surface area and were operated with a recirculation rate of $5.8 \mathrm{~L} \mathrm{~d}^{-1}$. ${ }^{b} \mathrm{NH}_{4}{ }^{+} \mathrm{N}$ volatilized in the air was equal to initial $\mathrm{NH}_{4}{ }^{+} \mathrm{N}$ in manure minus the remained $\mathrm{NH}_{4}{ }^{+} \mathrm{N}^{-}$in manure minus the $\mathrm{NH}_{4}{ }^{+} \mathrm{N}$ recovered in the acidic solution. CFA is the average of data collected during the experimentation time. dAlkali was added to manure to raise pH. Data are average of duplicate reactors during 30 days of experiment. Data expressed as $\mathrm{NH}_{+}^{+}$in this publication was converted to $\mathrm{NH}_{+}^{+}-\mathrm{N}$. eManure was aerated to raise pH. Data are average of duplicate reactors during 18 days of experiment. ${ }^{~} A l k a l i$ was added to manure to raise $\mathrm{pH}$. Data are average of duplicate reactors during 18 days of experiment. sAlkali was added to manure to raise pH. Data are average of duplicate reactors during 25 days of experiment (Table 2).

as mitigating $\mathrm{NH}_{3}$ emissions when applying digestate to crops. In this sense, when GMPT is applied to digested manure, an important reduction of ammonia in the digestate is observed, recovering $\mathrm{N}$ for further use as fertilizer $\left(\mathrm{NH}_{4}\right)_{2} \mathrm{SO}_{4}$, while reducing the ammonia emission potential of digested manure.

Moreover, the final digestate $\mathrm{pH}$ was kept around 7.7-8.0 (Figure 3), which is convenient to incorporate the digestate into arable soils at the end of the anaerobic process. Another advantage of using the gas-permeable membranes was that soluble carbonaceous compounds did not pass through the membrane (Vanotti and Szogi, 2015). According to Table 1 , while the $\mathrm{NH}_{4}{ }^{+}$was significantly reduced, TS, VS and CODt remained almost stable from the beginning to the end of the experiment.

The non-significant VS reduction was probably due to the anaerobic digestion process still occurring in the jars. This technology represents a good example of mitigation of environmental impacts caused by agriculture and nutrient recycling due to recovery of an end product (ammonium salt fertilizer) for agriculture application.

In summary, ammonia was successfully recovered from digestate using gas-permeable membranes. Removal and recovery efficiencies were 91 and $62 \%$ respectively, being possible to increase this recovery efficiency if the area of the membrane system is adjusted to maximize $\mathrm{N}$ recovery efficiency and to shorten $\mathrm{N}$ recovery time. Therefore, $\mathrm{N}$ recovery from digestate is a good strategy to reduce $\mathrm{N}$ contents in digestate effluents to be safely incorporated into arable soil in nitrogen vulnerable zones (NVZ).

\section{Acknowledgements}

Cooperation with USDA-ARS Project 608213630-005-00D "Innovative Animal Manure Treatment Technologies for Enhanced Environmental Quality" is grateful acknowledged. Mention of trade names or commercial products in this article is solely for the purpose of providing specific information and does not imply recommendation or endorsement by the U.S. Department of Agriculture.

\section{References}

Amon, B.; Kryvoruchko, V.; Amon, T.; Zechmeister-Boltenstern, S. 2006. Methane, nitrous oxide and ammonia emissions during storage and after application of dairy cattle slurry and influence of slurry treatment. Agriculture, Ecosystems and Environment 112: 153-162. 
American Public Health Association [APHA]. 1989. Standard Methods for the Examination of Water and Wastewater. 17ed. APHA, Washington, DC, USA.

Bacenetti, J.; Negri, M.; Fiala, M.; Gonzalez-García, S. 2013. Anaerobic digestion of different feedstocks: impact on energetic and environmental balances of biogas process. Science of Total Environment 463-464: 541-551.

Carrosio, G. 2014. Energy production from biogas in the Italian countryside: modernization vs. repeasantization. Biomass and Bioenergy 70: 141-148.

Chen, Y.; Cheng, J.J.; Creamer, K.S. 2008. Inhibition of anaerobic digestion process: a review. Bioresource Technology 99: 404464.

European Council. 1991. Council Directive of 12 December 1991 Concerning the Protection of Waters Against Pollution Caused by Nitrates from Agricultural Sources (91/676/EEC). Available at: <http://eur-lex.europa.eu/LexUriServ/LexUriServ.do?uri= CELEX:31991L0676:EN:HTML > [Accessed Aug. 20, 2015].

García-Gonzalez, M.C.; Vanotti, M.B.; Szogi, A.A. 2015. Recovery of ammonia from swine manure using gas-permeable membranes: effect of aeration. Journal of Environmental Management 152: 19-26.

García-Gonzalez, M.C.; Vanotti, M.B. 2015. Recovery of ammonia from swine manure using gas-permeable membranes: effect of water strength and $\mathrm{pH}$. Waste Management 38: 455-461.

Hansen, K.; Angelidaki, I.; Ahring, B. 1998. Anaerobic digestion of swine manure: inhibition by ammonia. Water Research 32: 5-12.
Hejnfelt, A.; Angelidaki, I. 2009. Anaerobic digestion of slaughterhouse by-products. Biomass and Bioenergy 33: 10461054.

Lauterbock, B.; Nikolausz, M.; Lv, Z.; Baumgartner, M.; Liebhard, G.; Fuchs, W. 2014. Improvement of anaerobic digestion performance by continuous nitrogen removal with a membrane contactor treating a substrate rich in ammonia and sulphide. Bioresource Technology 158: 209-216.

National Research Council [NRC]. 2002. The Scientific Basis for Estimating Air Emissions from Animal Feeding Operations. National Academy Press, Washington DC, USA.

Nkoa, R. 2014. Agricultural benefits and environmental risks of soil fertilization with anaerobic digestates: a review. Agronomy of Sustainable Development 34: 473-492.

Procházka, J.; Dolejs, P.; Maca, J.; Dohanyos, M. 2012. Stability and inhibition of anaerobic processes caused by insufficiency or excess of ammonia nitrogen. Applyed Microbiology Biotechnology 93: 439-47.

Ravishankara, A.R.; Daniel, J.S.; Portmann, R.W. 2009. Nitrous oxide $\left(\mathrm{N}_{2} \mathrm{O}\right)$ : the dominant ozone-depleting substance emitted in the 21st Century. Science 326: 123-125.

Sung, S.; Liu, T. 2003. Ammonia inhibition on thermophilic anaerobic digestion. Chemosphere 353: 43-52.

Vanotti, M.B.; Szogi, A.A. 2015. Systems and methods for reducing ammonia emissions from liquid effluents and for recovering the ammonia. US Patent number 9.005.333. US Patent and Trademark Office, Washington, DC, USA. 